Tom Clayton*

\title{
Foreword What Is Shakespeare? Who Is He? And When Is Shakespeare Himself Again?
}

The accuracy and thoroughness of the editors' introduction leaves a foreword with little to do but say so and invite the reader attracted to the titular subject of this collection to move on at once to that introduction and the stimulating and insightful contents introduced, leaving the foreword to go its own Willful way, as loosely suggested by its own title and the concerns of the author with the Shakespeare that was and is, though less and less recognizable in what an aging few might see as his imperial new clothes, but others would say because he is less and less often to be seen. ${ }^{1}$

The existence of this collection and its origins in Multicultural Shakespeare are correlative with the history of 'Shakespeare' in the decades since the 1960s. The proliferation of new and ever more complex ways of doing, seeing, understanding, and expressing everything imaginable and a great deal not has perforce generated new dialects and vocabularies-academic and otherwise - according to the objects as apprehended at the time, and the more technical the objects and relations perceived/conceived, the more technical or otherwise exotic the language embodying them. Does it go without saying that that language is ever further from dramatic objects as heretofore conceived, like persons-in-action (Aristotle's and Greek's gender-neutral $\pi \rho \alpha ́ \tau \tau \omega \nu \tau \varepsilon \varsigma$ ) and their dialogue? Those of course - not only the plays but the poems - where interest in Shakespeare begins and in significant degree ends. Before appropriation, which constitutes adaptation and discursive treatments of every kind, including criticism - without which, in the broad sense, Shakespeare would not be.

\footnotetext{
* Regents Professor Emeritus, Department of English Language and Literature, University of Minnesota, Minneapolis.

1 'Richard's himself again' is, of course, the exultant declaration in Richard III that became Shakespeare's posthumously.
} 
Persons who now concentrate primarily or prominently on Shakespeare's text are editors, linguists, literary critics, readers, and those connected with theatrical performance. Somewhat facetiously, these might be called Shakespeareans 'proper' for their concentration on Shakespeare's works. Shakespeareans otherwise concerned have a substantial part - if not all-of their interest in other fields, as is the case with most of the papers in the present collection. This is obvious from the titles, including the title of the collection, the keywords, and the sparsity of quotation. Among the forty-nine keywords (by my count), four play-titles occur: Coriolanus, Hamlet twice, King Lear, and The Tempest.

Nothing I say about any of these valuable contributions to knowledge should be construed as faulting any: they do what they do very well, and what they do has value.

Shakespeare the poet-playwright matters ultimately because his works have value in their expression and in what is expressed - first, last, and always in the texts, without which there would be no performance; and there is good reason to think that Shakespeare thought of his own plays as literature, too, not only as playscripts - at whatever stage they became either. Shakespeare's works need earnest and constant professing, and still are professed in many places, but less, perhaps, as time passes, not because the study of his works has less value but because equal or greater value is claimed and pressed for alternatives, whether in the corridors of power and utility or in the groves of academe where fashion holds sway as much as value almost always, and almost everywhere. Not unlike Real Life.

Shakespeare needs active professing everywhere, especially with students, to be kept visibly and efficaciously as much alive in reception and assimilation as he is in potentiality. One problem is that in higher-educational academe, teaching — or what I would call personal professing — necessarily takes second place to productivity, especially in universities, and productivity means one thing mainly if not only: publication. And publication demands contributions to knowledge and originality, sometimes of almost any kind. Which thought brought irresistibly to mind the following lines from a speech by the Duke in the Problem Play, or Dark Comedy (so-called), Measure for Measure, who is back in Vienna - or Ferrara, as Gary Taylor suggested and seems to have been the case-disguised as a friar to observe public life in the city and, at this point, speaking as the friar in context, as the Duke in disguise, for Shakespeare in part, and for the experience and reflection of the reading or hearing audience.

Escalus. What news abroad i' th' world?

Duke (as friar). None, but that there is so great a fever on goodness, that the dissolution of it must cure it: novelty is only in request; and it is as dangerous to 
be aged in any kind of course, as it is virtuous to be constant in any undertaking. There is scarce truth enough alive to make societies secure; but security enough to make fellowships accurst: much upon this riddle runs the wisdom of the world. This news is old enough, yet it is every day's news. $(3.2 .215-224)^{2}$

It is obvious that the Duke's surrogate, Escalus, is being at once conversational, curious, thematically pointed, and the 'straight man' with 'What news abroad i' th' world?' asked of the Friar, who has been around and knows the world as an itinerant, confessor, and sage. At the end, the Friar, about to resume his identity as Duke, adds still as Friar, for good and witty measure,

... the Duke

Dare no more stretch this finger of mine than he

Dare rack his own: his subject am I not,

Nor here provincial. My business in this state

Made me a looker on here in Vienna,

Where I have seen corruption boil and bubble

Till it o'er-run the stew; laws for all faults,

But faults so countenanced, that the strong statutes

Stand like the forfeits in a barber's shop,

As much in mock as mark. (5.1.311-320)

Without going further into this speech - in a foreword, forsooth?! — starkly characterizing a corrupt city like the Chicago I saw in a recent film, Widows (2018), I give the next passage that came to mind at this juncture, from another Dark Comedy - and the talkingest, thinkingest, still ever-kinetic Troilus and Cressida 2.2, at the centre of which is the question of value and of reasons for taking action. The subject of discussion is Helen of Troy, and whether she should be returned to her husband Menelaus or kept at the cost of war with the Greeks. Hector says, 'She is not worth what she doth cost in the keeping' $(2.2 .52),{ }^{3}$ to which Troilus replies (Escalus-like), inaugurating and sounding the theme of the debate, 'What's ought but as 'tis valued?' To which Hector cogently replies,

${ }^{2}$ References to Measure for Measure are to the Arden Shakespeare, edited by J. W. Lever (London: Thomas Nelson, 1998).

3 References to Troilus and Cressida are to the Arden Shakespeare, edited by Kenneth Palmer (London: Methuen, 1982). 
But value dwells not in particular will;

It holds his estimate and dignity

As well wherein 'tis precious of itself

As in the prizer. 'Tis mad idolatry

To make the service greater than the god;

And the will dotes that is attributive

To what infectiously itself affects,

Without some image of the affected merit. (2.2.54-61)

The sound valuation followed by the rousingly advocated sell-out. Hector's passionate oration moves toward the - at first glance surprising - conclusion:

Paris and Troilus, you have both said well,

And on the cause and question now in hand

Have glozed, but superficially....

If Helen then be wife to Sparta's king,

As it is known she is, these moral laws

Of nature and of nations speak aloud

To have her back return'd: thus to persist

In doing wrong extenuates not wrong,

But makes it much more heavy. Hector's opinion

Is this in way of truth; yet ne'ertheless,

My spritely brethren, I propend to you

In resolution to keep Helen still,

For 'tis a cause that hath no mean dependence

Upon our joint and several dignities. ... (2.2.164-166; 184-194)

Dignities indeed. Brazenly keeping the booty and hoping to save face at the cost of hundreds of human lives. Now when and where (not) have we seen that before? On the literary side, it may be noted that equally eloquent speeches may be in prose (the Duke-Friar's) or in verse (Hector's), with notable differences, not least in the fact that verse dictates stress and scores meaning (what I call semetrics).

A third 'Dark' Comedy, All's Well That Ends Well, brings me to a personal anecdote that says much about the profession in some places then-forty years ago - if not now. I submitted a revisionary essay called 'How Does All's Well End Well?' to a well-respected scholarly journal in which I had published. The essay received no fewer than five referees' readings, the first undecided, the second strongly negative, the third and fourth strongly positive, the fifth negative 
with suggestions for drastic (and reductive) revision. The editor concluded his report to me, 'If you think you can alter it to meet the objections of two of our readers and wish to return it to us there remains a chance that it would gain acceptance (but no guarantee).' The history suggests that in the end, at least, the editor did not want to publish the essay, for whatever reasons.

The first negative report (\#2) read,

[27 April 1979. Reject.] An energetic, persistent close reading of the play that, finally, does not add up to very much. There is a great deal of sifting of nuance here, some of it to the point and illuminating, some of it over-subtle, some of it off the mark. The author's intentions are intelligent, his industry admirable, his idea promising; but his essay seems more of a rough draft of an idea than a final, polished exposition of it.

The first positive (\#3),

1. [May 1979. Accept.] This is an important revisionary essay which demonstrates - I think quite strongly — that AWTEW can be considered a typical Shakespearean comedy rather than a problem play. The examination of Bertram, of Parolles, and especially of the bed-trick and of Bertram's relationship to Helena [sic; incomplete]. Then he can more simply account, as he does at the beginning and end of the essay, for the play's title and epilogue. The writing here is clear and straightforward [sic]; the scholarship apparently impeccable; the research comprehensive.

I conclude with this history because it reveals aspects of the academic literary profession, not with the radiance and illumination of dramatic art, but as through a glass darkly from anonymous but very real academics. It is obvious that the two evaluations cannot both be right. Which, if either is to be trusted, becomes a matter for scrutiny and judgment, but the predominance of abstractions vs specificity and detail speaks for itself, I think. After I read the editor's discouraging invitation to revise and resubmit, I shrugged and filed the essay, not submitting it again anywhere, the sadder but very much the wiser for my experience of the profession in the shade. The editor's decision now reminds me of Hector's: certainly, the editor preferred the expediency of deferring to his negative readers to showing the courage and principle to print a controversially novel reading of the play. So much for attempted truth vs 'our joint and several dignities'. 